\title{
Water holds Poland back, says Gierek
}

Poland's future "socio-economic development" may be "seriously hampered" by the shortage and inefficient use of water and the threat of its increasing pollution, according to a resolution of the Twelfth Plenary Session of the Central Committee of the Polish United Workers' Party which met earlier this month.

This resolution was a response to a massive report on the role of science in the country's development, presented by Edward Gierek, First Secretary of the Central Committce. Among many somewhat general statements--the need to save energy and natural resources, the growing importance of management efficiency, the expansion of research and the role of the Polish Academy of Sciences-the water problem was treated in far greater detail and in a tone of considerable urgency.

Until now, official Polish sources have seemed somewhat reluctant to allow water pollution to become a matter of public discussion. Enquiries from foreign specialists and journalists (including Nature) tend to meet with noncommittal statements implying that all is well, or at least well in hand. The evidence for pollution is therefore somewhat anecdotal-Sunday fishermen on the Vistula banks who stress that they would never dare eat their catch, or the Poznan joke about the man who fell into the city's artificial boating lake and was pulled out drunk on the waste waters of the brewery. Dissident sources would even claim that censorship regulations categorically forbid the reporting of certain aspects of water pollution at all.

Certainly the resolution of the Twelfth Plenum mentions pollution; but only, as it were, as a pending threat. The matters raised by $\mathrm{Mr}$ Gierek himself and for which the resolution proposes practical countermeasures are largely those of management.

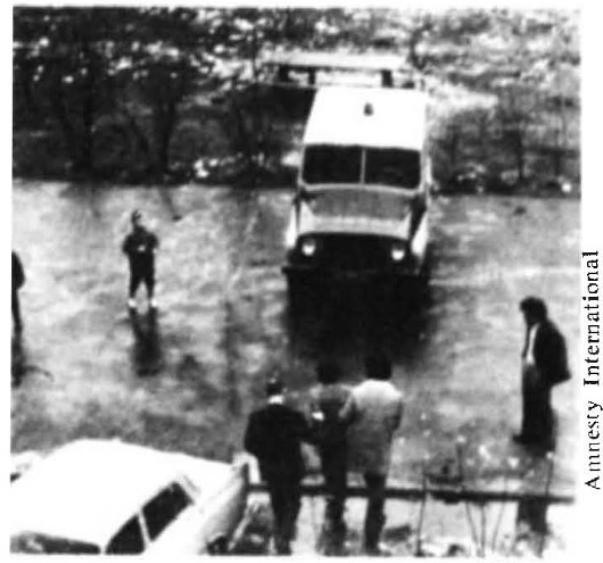

The arrest of Podrabinek, A pril 1977
Earlier this year, K. Frankowski, the Director of the Wroclaw provincial water conservancy, speaking on Warsaw television, pointed out that Polish water resources now come under no less than three ministries and numerous local authorities. In order to implement the existing "Outline of the long-term plan of water economy in Poland", he urged the establishment of a single responsible body to coordinate all measures dealing with water conservation.

Although $\mathrm{Mr}$ Gierek made no direct reference to Frankowski's proposals, he stressed that the water problem is "nationwide in scope" and must be "viewed, formulated and resolved" from this point of view. By the end of the century, he said, Poland will need an annual 40,000 million $\mathrm{m}^{3}$ of water, to satisfy the needs of the population, agriculture and industry. Poland's water resources are at the "lower end of the scale" for Europe. Nevertheless, he stressed, it is not their "global dimensions" which are the main problem. but their distribution.

Immediate proposals to improve the distribution of water resources are based on the development of the Vistula whose basin accounts for some $55 \%$ of Poland's surface water resources. Some $33 \%$ of Poland's urban population, and a significant proportion of industry are located in the five main conurbations on the river.

The development of the Vistula, said $\mathrm{Mr}$ Gierek, thus "occupies a key position in the whole of the water economy".

More practically, under the new scheme for the Vistula, some 220,000 ha of land, at present unused, would become available for intensive farming, and a further $1,000,000$ ha arable land would be protected from flooding. The Vistula itself would become an up-to-date water-way, usable for an average of over 300 days a year, and removing the load from the other

\section{Londoner may defend dissident}

Aleksandr Podrabinek, the Moscow paramedic who wrote Punitive Medicine, a 265-page samizdat exposé of political misuse of psychiatry in the Soviet Union is expected to be brought to trial shortly under Article 191-1 of the Soviet Penal Code ("malicious slander").

$\mathrm{Mr}$ Louis Blom-Cooper. a London QC. who has been compiling a defence file on Podrabinek. has applied for a visa to attend the trial. Although this has not yet been granted, a fellowlawyer, Mr Brian Wrobel, visited Moscow earlier this month and spoke

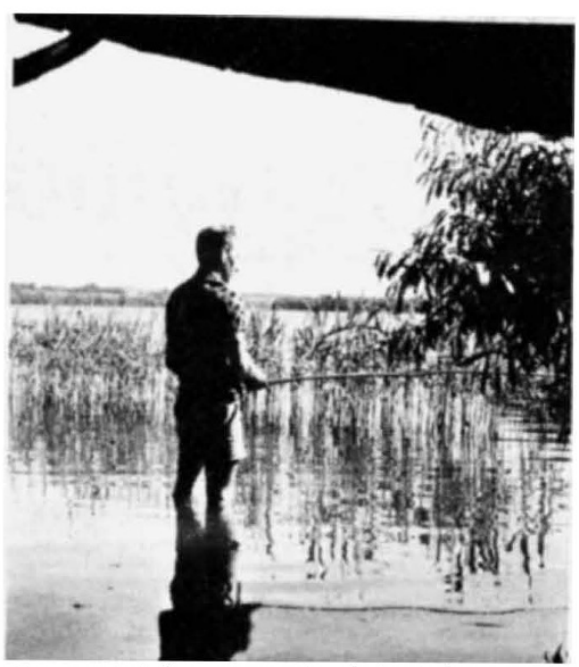

Tranquil fishing in Poland, but the same anglers don't dare eat their catch.

sectors of the Polish transport system by some 100 million tonnes of cargo per year. Hydroelectric power stations at the locks could accommodate generating sets of some $16,000 \mathrm{MW}$ and there would be considerable fringe benefits to town and country planning and to tourism.

On behalf of the Politburo, Mr Gierek proposed that the programme for the management of the Vistula and its water economy should be presented to the next Party Congress as "one of the most important tasks for the coming decades". Modestly, he suggested that should the members of the Central Committee share this opinion "it would be advisable" to express it in a separate resolution.

The resolution framed in answer to his appeal--which is some six times the length of that accepting the remainder of the science and technology report-essentially reitcrates his main proposals, appeals to "scientists and all professions" and the whole nation to make a "creative contribution" to the development of the Vistula, and instructs the government to prepare a programme of works to be undertaken in 1981-85.

Vera Rich

with representatives of various legal bodies in Moscow, none of whom ruled out the possibility of $\mathrm{Mr}$ BlomCooper's participation in the trial. One such person - the head of the Moscow city College of Advocates, has stated that if $\mathrm{Mr}$ Blom-Cooper telephones him hefore leaving London. he would be willing to see him.

Perhaps even more significantly, the Foreign and Commonwealth Office has backed $\mathrm{Mr}$ Blom-Cooper's visa request-an action which appears to he unprecedented. at least as far as the Soviet Union is concerned. 